\title{
КОМП'ЮТЕРИЗОВАНА СИСТЕМА КОМПЛЕКСНОГО МОНІТОРИНГУ Й КЕРУВАННЯ МІКРОКЛІМАТОМ ПРОМИСЛОВИХ ТЕПЛИЦЬ НА БАЗІ НЕЧІТКОЇ ЛОГІКИ
}

\section{І. С. Лактіонов, О. В. Вовна, М. О. Бережний, В. А. Лебедєв}

ДВНЗ «Донецький національний технічний університет»

пл. Шибанкова, 2, м. Покровськ, 85300, Україна. E-mail: ivan.laktionov@donntu.edu.ua

Представлено результати досліджень зі створення комп'ютеризованої системи комплексного моніторингу й керування мікрокліматом промислових теплиць. Задля отримання результатів авторами використано експериментальні методи дослідження багатоканальної автоматичної інформаційно-вимірювальної системи моніторингу регламентованих до вимірювального контролю параметрів мікроклімату, а також методи імітаційного моделювання систем керування на базі нечіткої логіки. Авторами спроектовано та сконструйовано дослідний зразок автоматизованої теплиці, який відповідає критеріям геометричної, динамічної та кінематичної подібності реальним промисловим тепличним комплексам. Синтезовано апаратно-програмне забезпечення системи моніторингу й керування мікрокліматом теплиць із використанням сучасних сенсорних, мікропроцесорних та програмних технологій. Оцінено якісні й кількісні показники реалізованих підсистем нечіткого керування обігрівом, зволоженням, штучним досвічуванням та вентиляцією зони вирощування, крапельного поливу, підкормки рослин вуглекислим газом та дозування добрив до поливного розчину.

Ключові слова: нечітке керування, теплиця, мікроклімат, комп'ютеризована система.

\section{КОМПЬЮТЕРИЗИРОВАННАЯ СИСТЕМА КОМПЛЕКСНОГО МОНИТОРИНГА И УПРАВЛЕНИЯ МИКРОКЛИМАТОМ ПРОМЫШЛЕННЫХ ТЕПЛИЦ НА БАЗЕ НЕЧЕТКОЙ ЛОГИКИ}

\section{И. С. Лактионов, А. В. Вовна, М. О. Бережной, В. А. Лебедев}

ГВУЗ «Донецкий национальный технический университет»

пл. Шибанкова, 2, г. Покровск, 85300, Украина. E-mail: ivan.laktionov@ donntu.edu.ua

Представлены результаты исследований по созданию компьютеризированной системы комплексного мониторинга и управления микроклиматом промышленных теплиц. Для получения результатов авторами использованы экспериментальные методы исследования многоканальной автоматической информационноизмерительной системы мониторинга регламентированных к измерительному контроля параметров микроклимата, а также методы имитационного моделирования систем управления на базе нечеткой логики. Авторами спроектирован и сконструирован опытный образец автоматизированной теплицы, отвечающий критериям геометрического, динамического и кинематического подобия реальным промышленным тепличным комплексам. Синтезировано аппаратно-программное обеспечение системы мониторинга и управления микроклиматом теплиц с использованием современных сенсорных, микропроцессорных и программных технологий. Оценены качественные и количественные показатели реализованных подсистем нечеткого управления обогревом, увлажнением, искусственным досвечиванием и вентиляцией зоны выращивания, капельного полива, подкормки растений углекислым газом и дозирования удобрений в поливной раствор.

Ключевые слова: нечеткое управление, теплица, микроклимат, компьютеризированная система.

АКТУАЛЬНІСТЬ РОБОТИ. За теперішніх тенденцій розвитку комп'ютеризованих методів і засобів автоматизації технологічних процесів перед фахівцями $з$ проектування технічних систем постає проблема вибору найбільш раціонального способу вирішення поставленого завдання. Спроба використати логіку першого порядку задля представлення знань у такій сфері як автоматизація вітчизняних тепличних виробництв $\epsilon$ не оптимальним підходом. Таким чином, проблема розробки комп'ютеризованих технологій із використанням сучасних методів та засобів автоматичного контролю й керування технологічними процесами в умовах теплиць $є$ актуальною для вітчизняного аграрного сектору.

Основною метою статті $є$ обгрунтування структури та програмна реалізація комп'ютерної системи моніторингу й керування основними технологічними режимами вирощування культур в умовах промислових теплиць на базі пакету розширення MATLAB \& Simulink Fuzzy Logic Toolbox ${ }^{\circledR}$.

На теперішній час існує ряд актуальних вимог до технологічних режимів вирощування культур в умовах захищеного грунту, які відображено у нормати- вних документах $[1,2]$. Також виходячи 3 актуальності проблеми автоматизації сільськогосподарських об'єктів і процесів у науковій літературі представлений широкий спектр досліджень із розробки систем автоматичного керування технологічними процесами в умовах теплиць із використанням нечіткої логіки [3-8]. Так, наприклад, у роботах [3-5] представлено результати розробки щодо моделювання та оптимізації систем автоматичного керування на базі Fuzzy-логіки у галузі сільського господарства. У роботі [6] проведено дослідження з побудови системи крапельного поливу для тепличних умов, яка враховує добову динаміку нестаціонарних процесів зміни температури повітря, вологості грунту та інтенсивності освітлення зони вирощування. У наукових працях $[7,8]$ реалізовано нечіткі системи віддаленого керування параметрами мікроклімату теплиць із використанням сучасних інфокомунікаційних технологій.

Проте, існуючі на теперішній час системи автоматичного керування мікрокліматом теплиць із використанням нечіткої логіки лише частково покривають регламентований $[1,2]$ перелік фізико- 
хімічних параметрів (температура повітря, вологість грунту, інтенсивність освітлення), що призводить до недостатньої ефективності використання апаратнопрограмних засобів керування технологічними режимами вирощування. Отже, задля усунення даного недоліку існуючих систем виникає необхідність у розробці комп'ютеризованої моделі з розширеним переліком контрольованих параметрів мікроклімату та оптимізованими зв'язками між вузлами системи.

МАТЕРІАЛИ І РЕЗУЛЬТАТИ ДОСЛІДЖЕНЬ. В якості базової методики розробки структурноалгоритмічної організації комп'ютеризованої системи моніторингу й керування мікрокліматом теплиць обрано структурну методику алгоритмізації на підс- таві принципу декомпозиції задачі дослідження на підзадачі [9], як показано на рис. 1.

На підставі результатів попередніх досліджень $[10,11]$ авторами статті обгрунтовано перелік контрольованих параметрів та створено дослідний зразок автоматизованої теплиці, який оснащено сукупністю сенсорів фізико-хімічних параметрів мікроклімату теплиць, а також реалізовано програмну компоненту агрегації й первинної цифрової обробки результатів спостережень в пакеті Simulink Support Package for Arduino Hardware ${ }^{\circledR}$. Перелік контрольованих параметрів із зазначенням відповідних сенсорів наведено в табл. 1, загальний вигляд експериментального зразка автоматизованої теплиці - на рис. 2 a,б.

Таблиця 1 - Перелік контрольованих параметрів із зазначенням відповідних сенсорів

\begin{tabular}{|c|c|c|}
\hline $\begin{array}{c}\text { Фізико-хімічні параметри } \\
\text { мікроклімату теплиці } \\
\end{array}$ & $\begin{array}{c}\text { Рекомендовані } \\
\text { діапазони варіювання } \\
\end{array}$ & $\begin{array}{c}\text { Модель сенсору, що } \\
\text { використовується }\end{array}$ \\
\hline $\begin{array}{l}\text { Температура повітря в зоні вирощування куль- } \\
\text { тур }\end{array}$ & $18-26^{\circ} \mathrm{C}$ & BME280 \\
\hline Вологість повітря в зоні вирощування культур & $60-90 \%$ & BME280 \\
\hline Температура грунту & $17-24^{\circ} \mathrm{C}$ & DS18b20 \\
\hline Вологість грунту & $65-80 \%$ & $\begin{array}{l}\text { Capacitive Soil Moisture } \\
\text { Sensor v. } 1.2 \\
\end{array}$ \\
\hline Температура розчину під час поливу & $22-26^{\circ} \mathrm{C}$ & DS18b20 \\
\hline $\begin{array}{l}\text { Ефективна освітленість зони вирощування ку- } \\
\text { льтур у видимому оптичному діапазоні з ура- } \\
\text { хуванням добової динаміки природного світла }\end{array}$ & $80-160 \mathrm{BT} / \mathrm{M}^{2}$ & GY-302 BH1750FVI \\
\hline $\begin{array}{l}\text { Концентрація вуглекислого газу в зоні } \\
\text { вирощування культур }\end{array}$ & $500-2000 \mathrm{ppm}$ & MG-811 \\
\hline Кислотність розчину при поливі & $6,0-8,0$ од. & Analog pH Meter Kit module \\
\hline Елекропровідність розчину при поливі & $1,5-2,5 \mathrm{мCM} / \mathrm{cm}$ & $\begin{array}{c}\text { Analog Electrical } \\
\text { Conductivity Sensor module }\end{array}$ \\
\hline $\begin{array}{l}\text { Швидкість руху потоків повітря в зоні } \\
\text { вирощування культур }\end{array}$ & $0,3-1,5 \mathrm{~m} / \mathrm{c}$ & Rev. P Wind Sensor \\
\hline
\end{tabular}

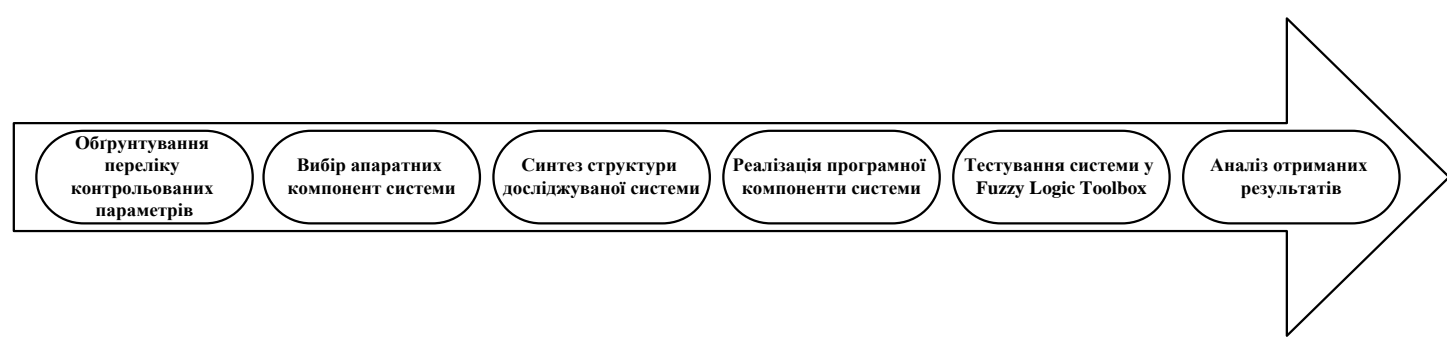

Рисунок 1 - Етапи розробки комп'ютеризованої системи комплексного моніторингу й керування мікрокліматом промислових теплиць

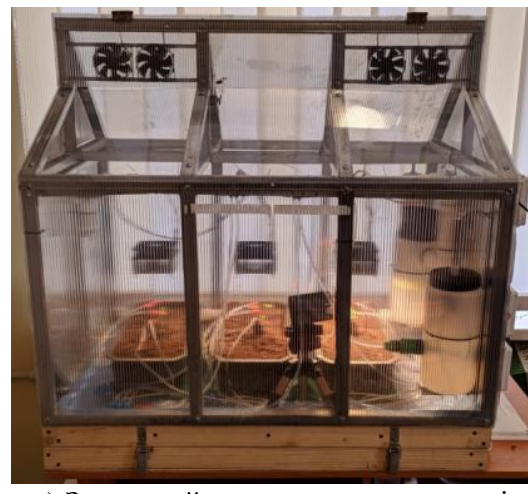

a) Загальний вигляд макету теплиці

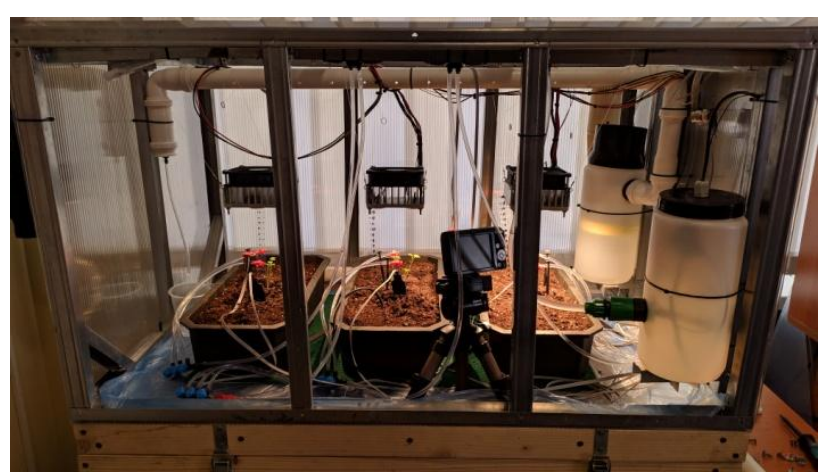

б) Загальний вигляд систем автоматичного керування

Рисунок 2 - Фото експериментального зразка автоматизованої теплиці 
На підставі викладеної вище інформації встановлено, що керування мікрокліматом теплиці виконується наступним чином:

- регулювання режимів обігріву теплиці здійснюється на підставі вимірювальної інформації щодо поточної температури повітря в зоні вирощування $\left(T_{\text {air }}\right)$ та швидкості руху потоків повітря $\left(V_{\text {air }}\right)$;

- керування зволоженням повітря здійснюється на підставі вимірювальної інформації від сенсорів температури $\left(T_{\text {air }}\right)$ й вологості ( $\left.W_{\text {air }}\right)$ повітря в зоні вирощування культур;

- регулювання режимів провітрювання теплиці здійснюється на підставі вимірювальної інформації від сенсорів температури $\left(T_{\text {air }}\right)$ й вологості $\left(W_{\text {air }}\right)$ повітря в зоні вирощування культур, швидкості руху потоків повітря $\left(V_{\text {air }}\right)$ та поточної концентрації вуглекислого газу $\left(\mathrm{CO}_{2}\right)$;

- дозування вуглекислого газу, що надходить до зони вирощування культур здійснюється на підставі вимірювальної інформації від сенсорів температури $\left(T_{\text {air }}\right)$ повітря, поточної концентрації вуглекислого газу $\left(\mathrm{CO}_{2}\right)$ та ефективної освітленості зони вирощування (LuxIntens);

- керування режимами роботи джерел штучного досвічування здійснюється на підставі вимірювальної інформації від сенсорів поточної концентрації вуглекислого газу $\left(\mathrm{CO}_{2}\right)$ та ефективної освітленості зони вирощування (LuxIntens);

- дозування добрив до поливного розчину здійснюється на підставі вимірювальної інформації від сенсорів кислотності $(p H)$ та електропровідності ( $E l$ prov);

- крапельне зрошення грунту здійснюється на підставі вимірювальної інформації від сенсорів температури $\left(T_{\text {soil }}\right)$ й вологості $\left(W_{\text {soil }}\right)$ грунту.

У залежності від функціонального призначення кожна із вищенаведених підсистем має два або три режими роботи. Два режими мають підсистеми логіка роботи, яких побудована на принципі вмикання/вимикання, а саме: зволоження повітря, крапельний полив, дозування добрив, штучне досвічування, підкормка вуглекислим газом. Три режими («Швидко», «Повільно», «Вимкнути») мають підсистеми, які потребують плавного регулювання режимів роботи: провітрювання й обігрів зони вирощування. Наприклад, підсистема провітрювання зони вирощування керує вентиляторами та вікном вентиляції, які, в свою чергу, можуть працювати в різних режимах інтенсивності, а саме: «Відкрити вікно на $90^{\circ}$ та ввімкнути вентилятори на повну потужність», «Відкрити вікно на $45^{\circ}$ та ввімкнути вентилятори на половину потужності», «Закрити вікно та вимкнути вентилятори».

Таким чином, на підставі обгрунтування лінгвістичних змінних і загального алгоритму функціонування в середовищі моделювання MATLAB \& Simulink Fuzzy Logic Toolbox ${ }^{\circledR}$ було розроблено структурну модель системи комплексного моніторингу й керування мікрокліматом промислових теплиць на базі нечіткої логіки, яку наведено на рис. 3.

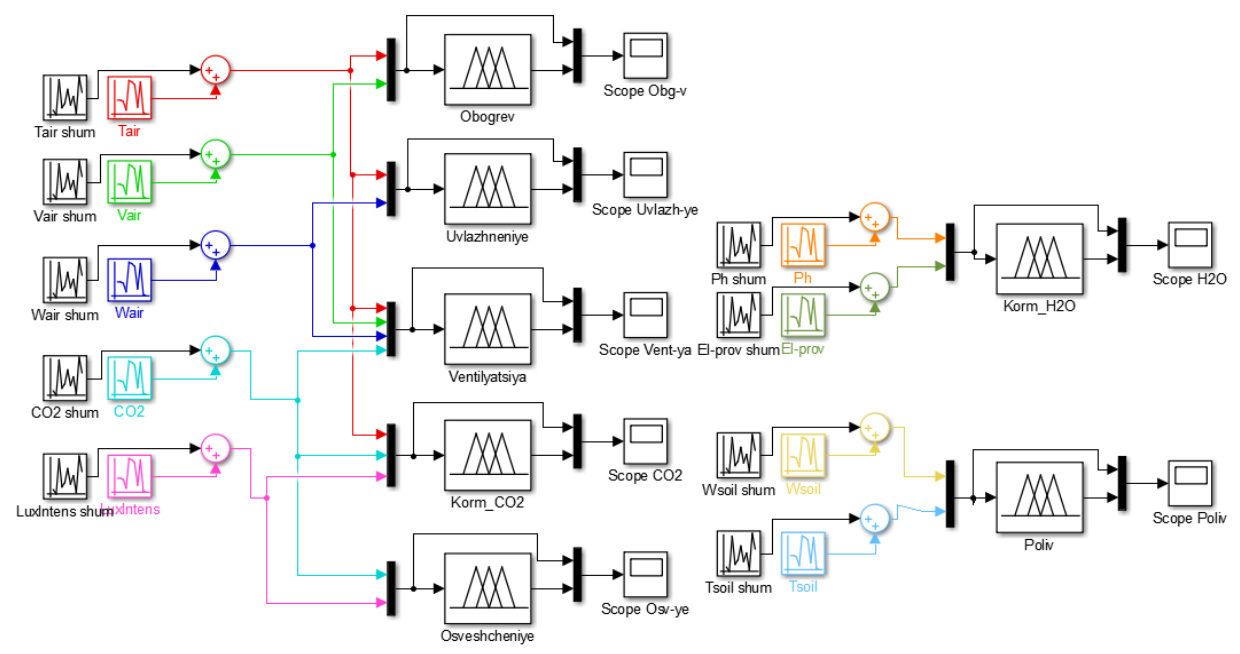

Рисунок 3 - Simulink-модель нечіткого керування мікрокліматом теплиць

Як показано на рис. 3 розроблена система керування складається 3 семи функціональних підсистем. На вхід кожної підсистеми надходить інформація з генераторів випадкових сигналів, які імітують роботу реальних сенсорів. Задля того, щоб максимально наблизити отримані результати моделювання із використанням теорії нечіткого керування, до вихідних сигналів кожного 3 датчиків додано шумову складову, яка за амплітудою рівна допустимій похибці відповідного сенсора. Далі ці сигнали надходять до входів відповідних підсистем нечіткого керування (fis-моделі). Для кожної підсистеми за допомогою програми нечіткої логіки задано ряд умов та правил результатом, яких є універсальне керування кожною підсистемою. Результати моделювання візуалізовано за допомогою осцилографів. Задля кількісного аналізу отриманих результатів імітаційного моделювання на кожний осцилограф подано синхронізовані в часі сигнали від сенсорів відповідних фізико-хімічних параметрів мікроклімату та результуючий сигнал з блоку нечіткого керування.

Програмну реалізацію підсистеми обігріву повітря зони вирощування культур наведено на рис. $4 a, \sigma$. 


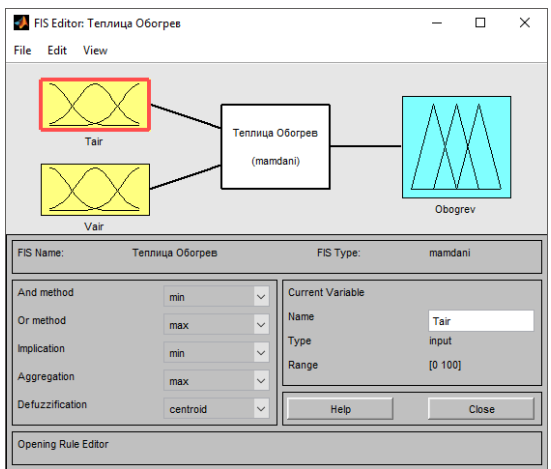

а) Блок-схема редактору функцій підсистеми обігріву

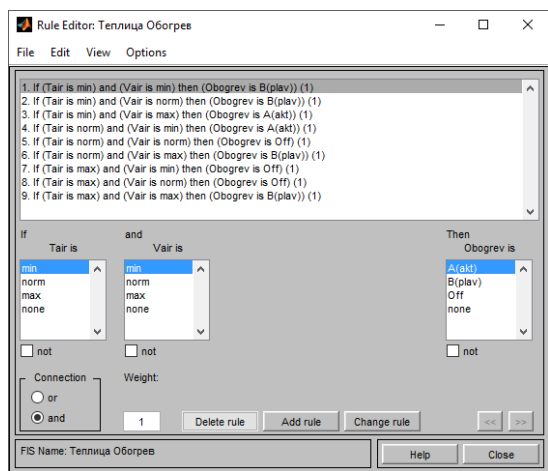

б) Редактор бази правил нечіткого керування обігрівом

Рисунок 4 - Програмна реалізація підсистеми нечіткого керування обігрівом теплиці

Реалізовані підсистеми керування мікрокліматом теплиць складаються $з$ відповідних редакторів функцій належності вхідних сигналів та результуючого сигналу керування, а також бази правил нечіткого керування. Для фазифікації вхідних сигналів обрано: трикутну форму - для допустимого діапазону зміни параметрів (див. табл. 1) та трапецієвидну для діапазонів, що виходять за допустимі межі. Фазифікацію вихідного сигналу реалізовано функціями трапецієвидної форми, у якості алгоритму нечіткого виведення використано алгоритм Мамдані.

У залежності від миттєвих значень вхідних сиг- налів датчиків температури й швидкості руху повітря в редакторі правил обирається відповідне рівняння функції керування, як показано в табл. 2.

У результаті розробки підсистеми обігріву повітря зони вирощування отримано результати моделювання, які наведено на рис. 5.

Як видно із аналізу результатів моделювання, які наведено на рис. 5, розроблений нечіткий регулятор приводить процес обігріву до рекомендованого стану, шляхом його адаптації до температури зони вирощування та швидкості руху потоків повітря.

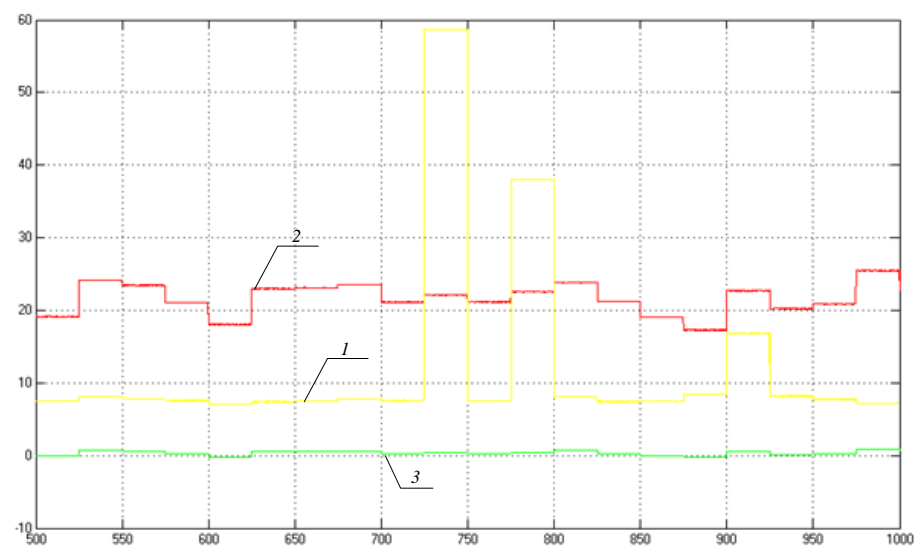

Рисунок 5 - Результати моделювання нечіткого керування підсистемою обігріву ( 1 - вихідний сигнал керування; 2 - вихідний сигнал сенсору температури; 3 - вихідний сигнал сенсору швидкості руху повітря)

Програмну реалізацію підсистеми зволоження повітря зони вирощування тепличних культур

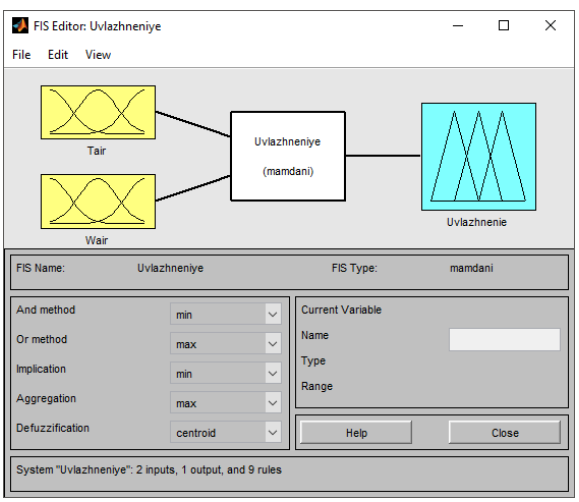

а) Блок-схема редактору функиій підсистеми зволоження наведено на рис. $6 a$, $б$.

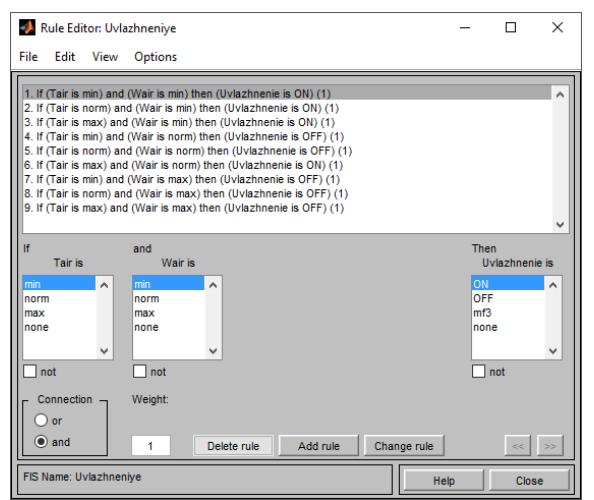

б) Редактор бази правил нечіткого керування зволоженням ання зволоженням повітря зони вирощування теплиці 
Таблиця 2 - Матриця відповідності до функцій належності параметрів підсистеми обігріву теплиці

\begin{tabular}{|c|c|c|c|}
\hline \multirow{2}{*}{$\boldsymbol{V}_{\text {air }}$} & \multicolumn{3}{|c|}{$\boldsymbol{T}_{\text {air }}$} \\
\cline { 2 - 4 } & Нижче норми & Норма & Вище норми \\
\hline Нижче норми & Активно & Виключено & Виключено \\
\hline Норма & Активно & Виключено & Виключено \\
\hline Вище норми & Повільно & Виключено & Виключено \\
\hline
\end{tabular}

У залежності від миттевих вхідних сигналів датчиків вологості й температури в редакторі правил

обирається відповідне рівняння функції керування підсистемою, як показано в табл. 3.

Таблиця 3 - Матриця відповідності до функцій належності параметрів підсистеми зволоження повітря

\begin{tabular}{|c|c|c|c|}
\hline \multirow{2}{*}{$\boldsymbol{W}_{\text {air }}$} & \multicolumn{3}{|c|}{$\boldsymbol{T}_{\text {air }}$} \\
\cline { 2 - 4 } & Нижче норми & Норма & Вище норми \\
\hline Нижче норми & Включено & Включено & Включено \\
\hline Норма & Виключено & Виключено & Включено \\
\hline Вище норми & Виключено & Виключено & Виключено \\
\hline
\end{tabular}

У результаті розробки підсистеми зволоження моделювання, які наведено на рис. 7. повітря зони вирощування отримано результати

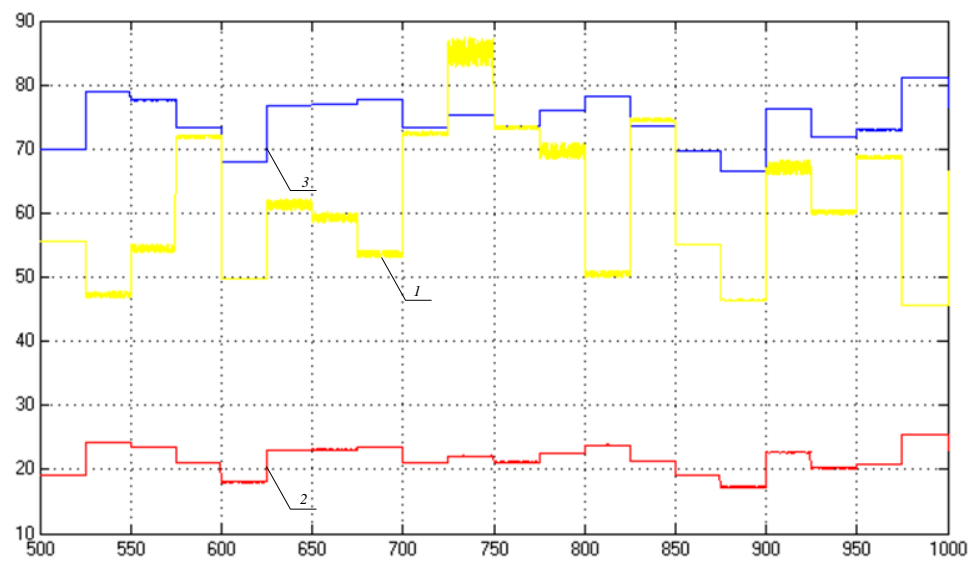

Рисунок 7 - Результати моделювання нечіткого керування підсистемою зволоження ( 1 - вихідний сигнал керування; 2 - вихідний сигнал сенсору температури; 3 - вихідний сигнал вологості)

Як видно із аналізу результатів моделювання, які наведено на рис. 7, розроблена підсистема керування зволоженням повітря зони вирощування теплиці приводить рівень вологи до регламентованого значення, шляхом його адаптації до температури й вологості зони вирощування.

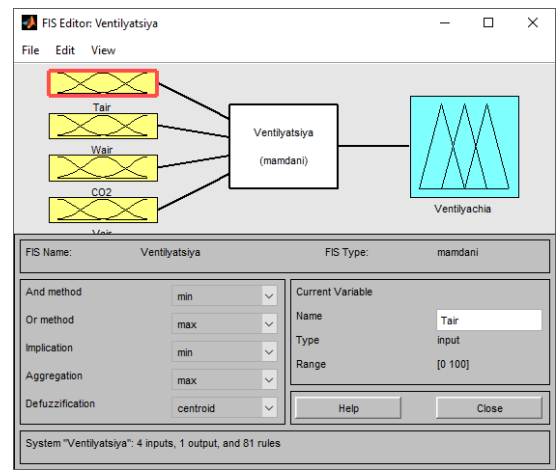

а) Блок-схема редактору функцій підсистеми вентиляиіі

Рисунок 8 - Програмна реалізація підсистеми керування вентиляцією зони вирощування теплиці

У результаті розробки підсистеми вентиляції зони вирощування отримано результати моделювання,
Програмну реалізацію підсистеми вентиляції зони вирощування культур наведено на рис. $8 a, \sigma$. Вихідний сигнал керування цією підсистемою залежить від поточних значень температури й вологості повітря, швидкості руху потоків повітря та концентрації вуглекислого газу.

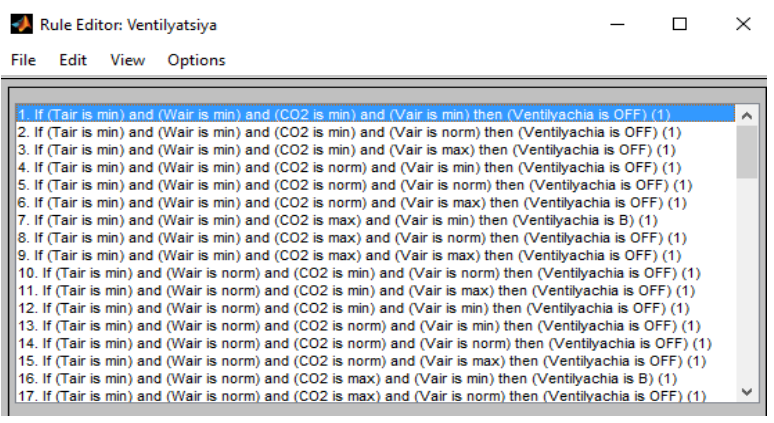

б) Фрагмент редактора бази правил нечіткого керування вентиляцією 


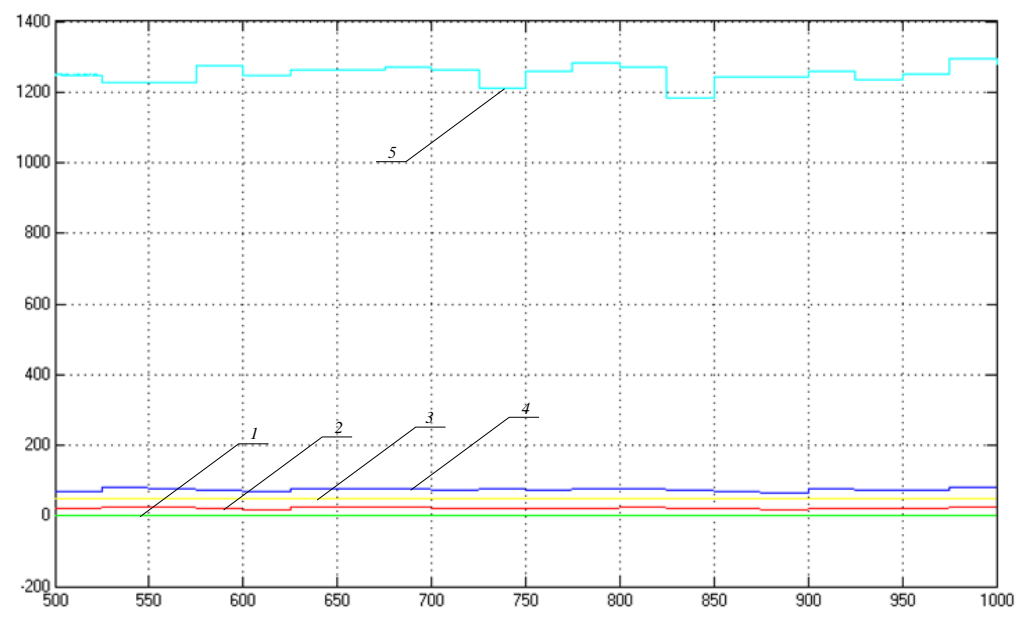

Рисунок 9 - Результати моделювання нечіткого керування підсистемою вентиляції ( 1 - вихідний сигнал сенсору швидкості руху повітря; 2 - вихідний сигнал сенсору температури; 3 - вихідний сигнал керування підсистемою вентиляції, 4 - вихідний сигнал сенсору вологості, 5 - вихідний сигнал сенсору концентрації $C O_{2}$ )

Як видно із аналізу результатів моделювання, які наведено на рис. 9, розроблена підсистема керування вентиляцією зони вирощування теплиці адаптує швидкість подачі чистого повітря до регламентованого значення із урахуванням поточних значень температури й вологості повітря, швидкості руху потоків повітря та концентрації вуглекислого газу.

Програмну реалізацію підсистеми дозування ву-

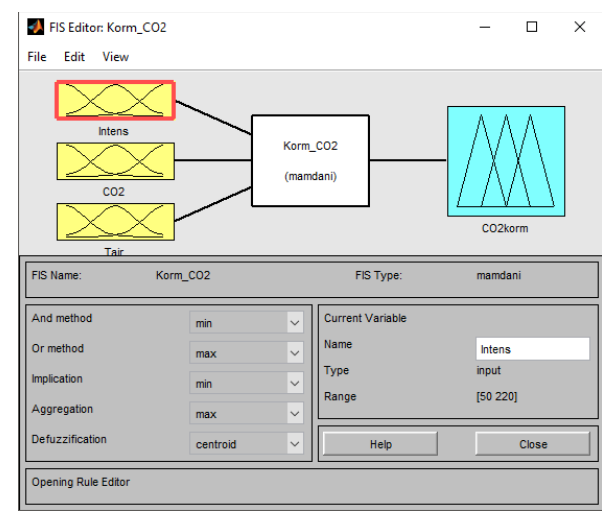

а) Блок-схема редактору функиій підсистеми дозування вуглекислого газу глекислого газу до зони вирощування культур наведено на рис. $10 a$, б. Вихідний сигнал керування цією підсистемою залежить від поточних значень температури повітря, концентрації вуглекислого газу та освітленості зони вирощування. У результаті розробки підсистеми дозування вуглекислого газу до зони вирощування отримано результати моделювання, які наведено на рис. 11.

Рисунок 10 - Програмна реалізація підсистеми керування дозуванням вуглекислого газу

У залежності від миттєвих вхідних сигналів датчиків температури повітря, концентрації вуглекислого газу та освітленості зони вирощування в редак- торі правил обирається відповідне рівняння функції керування, як показано в табл. 4.

Таблиця 4 - Матриця відповідності до функцій належності параметрів підсистеми дозування $\mathrm{CO}_{2}$

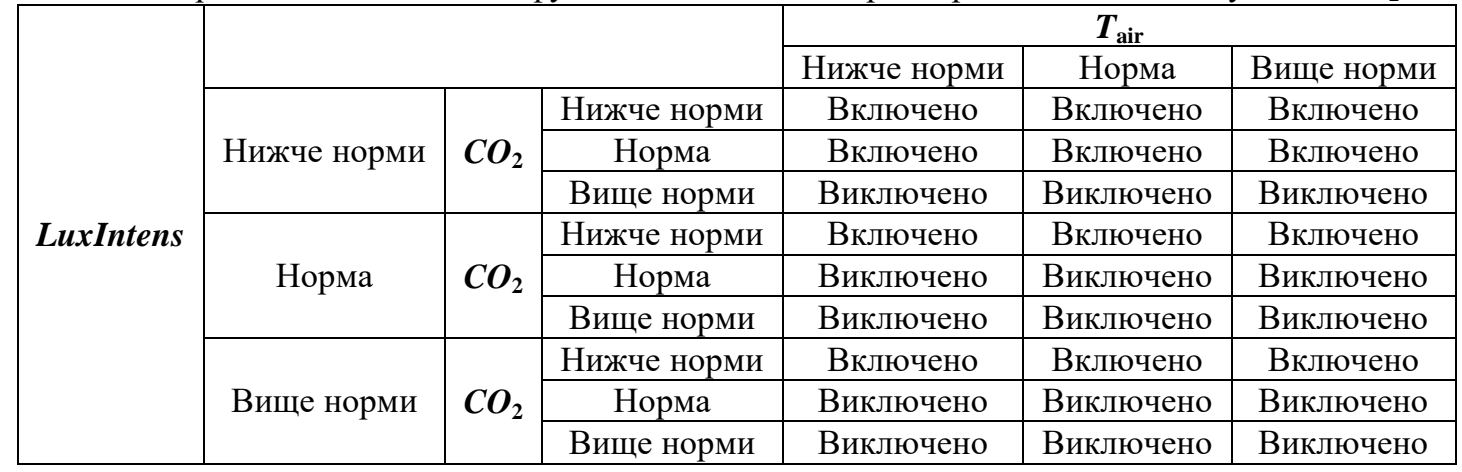




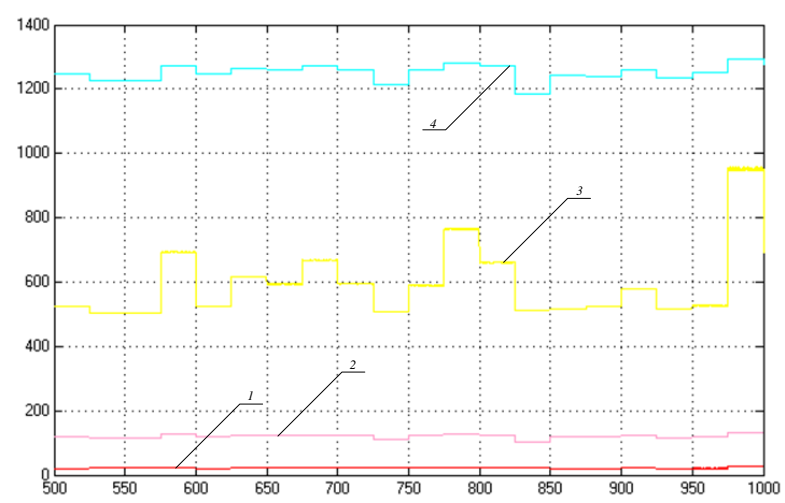

Рисунок 11 - Результати моделювання нечіткого керування підсистемою дозування $\mathrm{CO}_{2}(1-$ вихідний сигнал сенсору температури; 2 - вихідний сигнал сенсору інтенсивності освітлення; 3 - вихідний сигнал керування підсистемою дозування вуглекислого газу, 4 - вихідний сигнал сенсору концентрації $\mathrm{CO}_{2}$ )

Як видно із аналізу результатів моделювання, які наведено на рис. 11 , розроблена підсистема керування подачею вуглекислого газу до зони вирощування культур адаптує швидкість подачі концентрованого двоокису вуглецю на підставі вимірювального контролю температури повітря, концентрації вуглекислого газу та рівня освітлення теплиці.

Програмну реалізацію підсистеми штучного досвічування зони вирощування культур наведено на

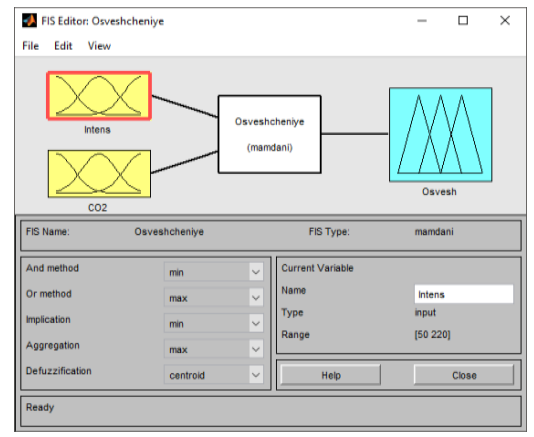

а) Блок-схема редактору функиій підсистеми штучного досвічування рис. $12 a$, б. Вихідний сигнал керування цією підсистемою залежить від поточних значень концентрації двоокису вуглецю та інтенсивності освітлення. У результаті розробки підсистеми штучного досвічування зони вирощування отримано результати моделювання, які наведено на рис. 13. Матрицю відповідності правил нечіткого керування даною підсистемою до функцій належності параметрів представлено в табл. 5.

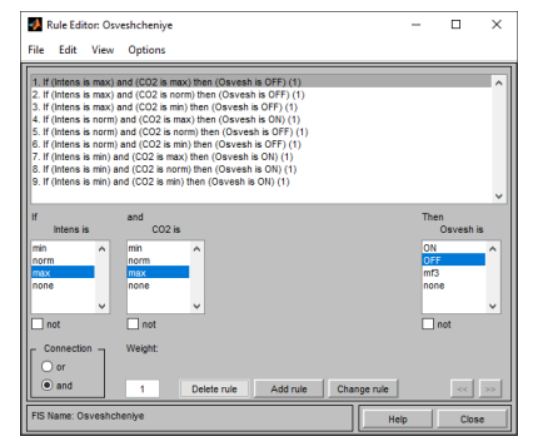

б) Фрагмент редактора бази правил нечіткого керування штучним досвічуванням

Рисунок 12 - Програмна реалізація підсистеми штучного досвічування зони вирощування

Таблиця 5 - Матриця відповідності до функцій належності параметрів підсистеми штучного досвічування

\begin{tabular}{|c|c|c|c|}
\hline \multirow{2}{*}{ LuxIntens } & \multicolumn{3}{|c|}{$\boldsymbol{C O}_{2}$} \\
\cline { 2 - 4 } & Нижче норми & Норма & Вище норми \\
\hline Нижче норми & Включено & Включено & Включено \\
\hline Норма & Виключено & Виключено & Включено \\
\hline Вище норми & Виключено & Виключено & Виключено \\
\hline
\end{tabular}

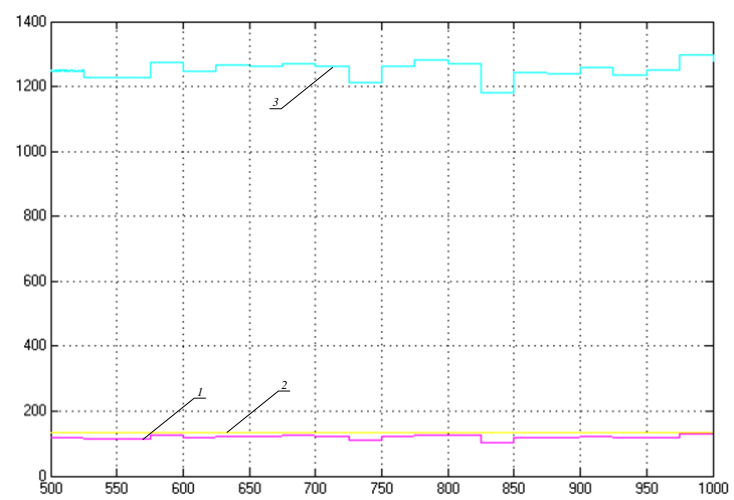

Рисунок 13 - Результати моделювання нечіткого керування підсистемою штучного досвічування ( 1 - сигнал сенсору освітлення; 2 - сигнал керування даною підсистемою, 3 - сигнал сенсору концентрації $\mathrm{CO}_{2}$ ) 
Як видно із аналізу результатів моделювання, які наведено на рис. 13, реалізована модель підсистеми керування режимами штучного досвічування зони вирощування культур адаптує інтенсивність джерела освітлення на підставі вимірювальної інформації від сенсорів концентрації вуглекислого газу та рівня освітлення теплиці.

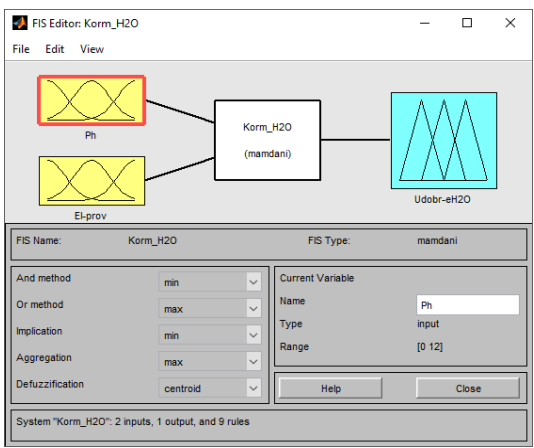

а) Блок-схема редактору функцій підсистеми дозування добрив до поливного розчину

Рисунок 14 - Програмна реалізація підсистеми дозування добрив до поливного розчину

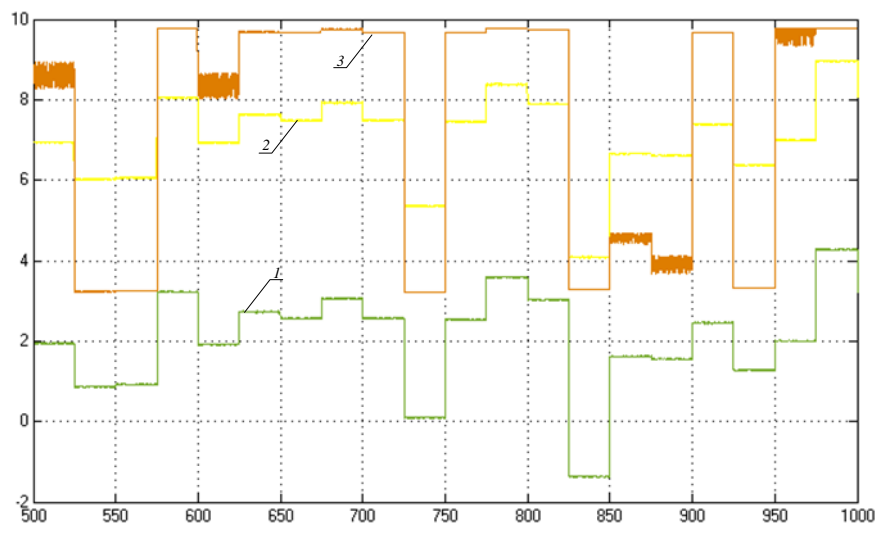

Рисунок 15 - Результати моделювання нечіткого керування підсистемою дозування добрив ( 1 - сигнал від сенсору електропровідності; 2 - сигнал керування підсистемою дозування добрив, 3 - сигнал від сенсору рН)

Як видно із аналізу результатів моделювання, які наведено на рис. 15, реалізована модель підсистеми оптимального дозування добрив адаптує інтенсивність їх внесення до поливного розчину на підставі вимірювальної інформації від сенсорів кислотності та електропровідності.

Підсистему керування режимами зволоження грунту реалізовано на базі технології крапельного

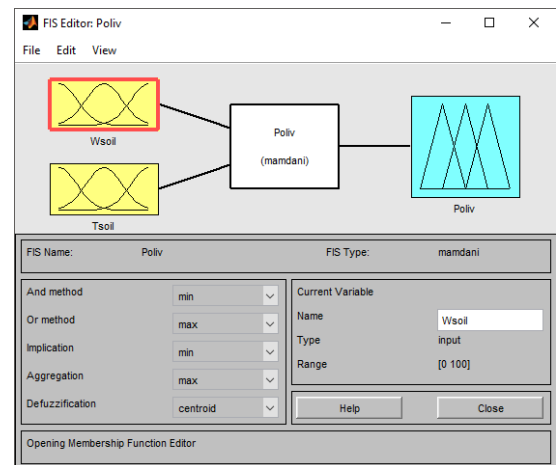

а) Блок-схема редактору функцій підсистеми поливу
Програмну реалізацію підсистеми дозування добрив до поливного розчину наведено на рис. $14 a$, б. Вихідний сигнал керування цією підсистемою залежить від виміряних значень кислотності та електропровідності розчину, результати моделювання, які наведено на рис. 15, матрицю відповідності правил керування - в табл. 6.

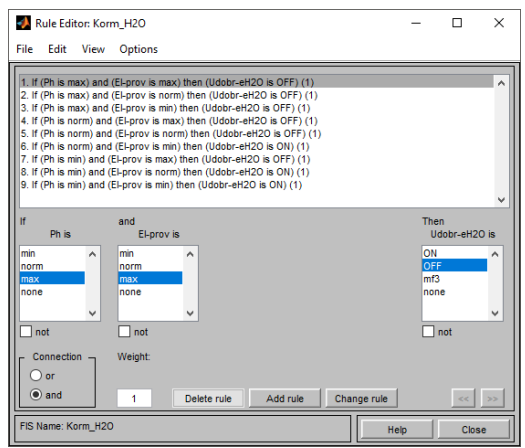

б) Фрагмент редактора бази правил нечіткого керування дозування добрив зрошення, яке здійснюється на підставі вимірювальної інформації від сенсорів температури й вологості грунту, як показано на рис. $16 a$, б. Під час розробки підсистеми керування поливом отримано результати моделювання, які наведено на рис. 17. Матрицю відповідності правил нечіткого керування даною підсистемою до функцій належності параметрів представлено в табл. 7.

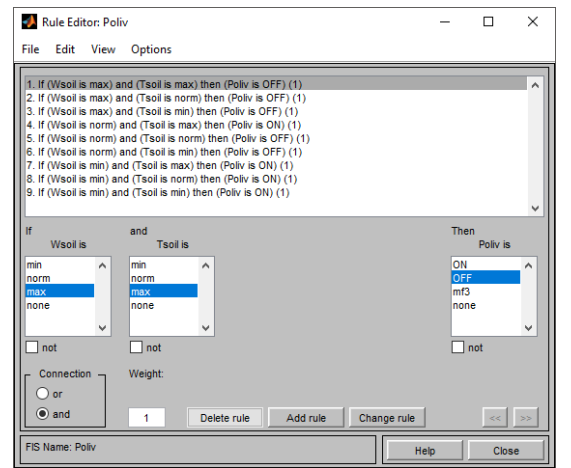

б) Фрагмент редактора бази правил нечіткого керування поливом

Рисунок 16 - Програмна реалізація підсистеми керування крапельним зрошенням 
Таблиця 6 - Матриця відповідності до функцій належності параметрів підсистеми дозування добрив до поливного розчину

\begin{tabular}{|c|c|c|c|}
\hline \multirow{2}{*}{$\boldsymbol{p H}$} & \multicolumn{3}{|c|}{ El-prov } \\
\cline { 2 - 4 } & Нижче норми & Норма & Вище норми \\
\hline Нижче норми & Включено & Включено & Виключено \\
\hline Норма & Включено & Виключено & Виключено \\
\hline Вище норми & Виключено & Виключено & Виключено \\
\hline
\end{tabular}

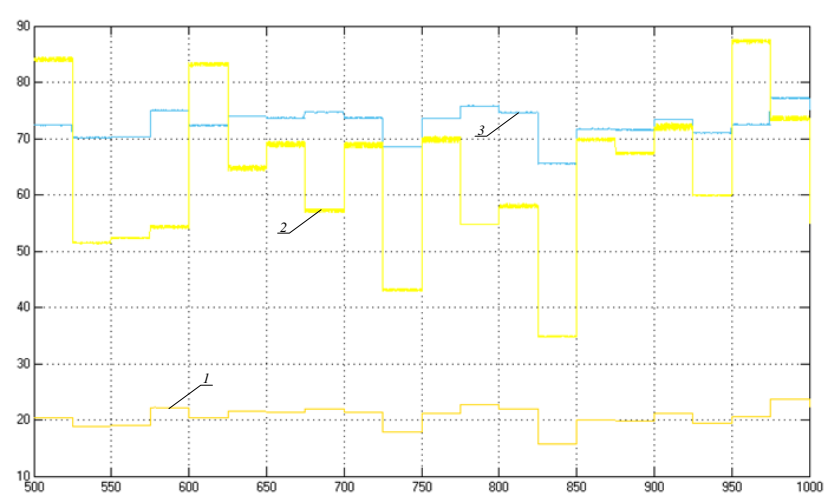

Рисунок 17 - Результати моделювання нечіткого керування крапельним поливом ( 1 - сигнал від сенсору температури грунту; 2 - сигнал керування крапельним поливом, 3 - сигнал від сенсору вологості грунту)

Таблиця 7 - Матриця відповідності до функцій належності параметрів підсистеми крапельного поливу

\begin{tabular}{|c|c|c|c|}
\hline \multirow{2}{*}{$\boldsymbol{W}_{\text {soil }}$} & \multicolumn{3}{|c|}{$\boldsymbol{T}_{\text {soil }}$} \\
\cline { 2 - 4 } & Нижче норми & Норма & Вище норми \\
\hline Нижче норми & Включено & Включено & Включено \\
\hline Норма & Виключено & Виключено & Включено \\
\hline Вище норми & Виключено & Виключено & Виключено \\
\hline
\end{tabular}

Як видно із аналізу результатів моделювання, які наведено на рис. 17, реалізована модель підсистеми крапельного зрошення адаптує інтенсивність подачі поливного розчину до кореневої системи вирощуваних культур.

ВИСНОВКИ. У статті вирішено актуальну науково-прикладну задачу обгрунтування структури та програмної реалізація комп'ютерної системи моніторингу й керування основними технологічними режимами вирощування культур в умовах промислових теплиць на базі пакету розширення MATLAB $\&$ Simulink Fuzzy Logic Toolbox ${ }^{\circledR}$. Основним науково-прикладним доробком статті $є$ : аналіз і логічне узагальнення відомих результатів наукових досліджень в заявленій предметній області; обгрунтування переліку фізико-хімічних параметрів мікроклімату теплиць, що підлягають автоматичному контролю; розробка структурно-алгоритмічної організації системи автоматичного керування технологічними режимами вирощування; програмна реалізація режимів функціонування системи керування мікрокліматом; якісний і кількісний аналіз отриманих результатів розробки комп'ютеризованої системи; обгрунтування перспективних напрямків подальших досліджень. Аналіз отриманих результатів досліджень запропонованої комп'ютеризованої системи підтвердив можливість іiі застосування в умовах вирощування культур на закритому грунті.

\section{ЛIТЕРАТУРА}

1. Both A. J., Benjamin L., Franklin J., Holroyd G., Incoll L. D., Lefsrud M. G., Pitkin G. Guidelines for measuring and reporting environmental parameters for experiments in greenhouses. Plant Methods. 2015. № 11. C. 1-18.

2. Food and Agriculture Organization of the United Nations. Good Agricultural Practices for greenhouse vegetable production in the South East European countries. Rome: FAO. 2017. 449 c.

3. Sriraman A., Mayorga R. V. Climate Control inside a Greenhouse: An Intelligence System Approach Using Fuzzy Logic Programming. Journal of Environmental Informatics. 2007. № 10 (2). C. 14-20.

4. Faouzi D., Bibi-Triki N., Mohamed B., Abune A. Optimization, Modeling and Simulation of Microclimate and Energy Management of the Greenhouse by Modeling the Associated Heating and Cooling Systems and Implemented by a Fuzzy Logic Controller using Artificial Intelligence. Informatica. 2017. № 41. C. 317-332.

5. Budi L. S., Wardhani R. M. The Application of Fuzzy Logic Control Systems on Harvesting Standard Operating Procedures Models of Sesame Crops in Indonesia. International Journal on Advanced Science, Engineering and Information Technology. 2017. № 7 (3). C. 1089-1097.

6. Izzuddin T. A., Johari M. A., Rashid M. Z. A., Jali M. H. Smart irrigation using fuzzy logic method. ARPN Journal of Engineering and Applied Sciences. 2018. № 13 (2). C. 517-522.

7. Chandraprabha Mrs., Uma K. Controlling of Green House Parameters through GSM and LabVIEW System. International Journal for Scientific Research \& Development. 2017. № 5 (07). C. 358-362. 
8. Algarin C. R., Cabarcas J. S., Llanos A. P. LowCost Fuzzy Logic Control for Greenhouse Environments with Web Monitoring. Electronics. 2017. № 6 (71). С. 1-12.

9. Бесекерский В. А., Попов Е. П. Теория систем автоматического управления: 4-е изд., перераб. и доп. СПб.: Профессия. 2003. 747 с.

10. Laktionov I. S., Vovna O. V., Zori A. A. Planning of remote experimental research on effects of green- house microclimate parameters on vegetable cropproducing. International Journal On Smart Sensing and Intelligent Systems. 2017. № 10 (4). C. 845-862.

11. Laktionov I., Vovna O., Bashkov Ye., Zori A., Lebediev V. Improved Computer-Oriented Method for Processing of Measurement Information on Greenhouse Microclimate. International Journal BIOautomation. 2019. № 23 (1). C. 71-86.

\section{COMPUTERIZED SYSTEM OF THE COMPLEX MONITORING AND CONTROL OF THE INDUSTRIAL GRENHOUSES MICROCLIMATE ON THE FUZZY-LOGIC BASIS}

I. Laktionov, O. Vovna, M. Berezhnyi, V. Lebediev

SHEE «Donetsk National Technical University»

Shybankova sq., 2, Pokrovsk, 85300, Ukraine. E-mail: ivan.laktionov@ donntu.edu.ua

Purpose. The structure substantiation and program realization of the computer monitoring and control system on the main technological regimes of crops growing under greenhouse conditions is the purpose of the article. The article presents results of experimental studies on improvement of the computer-oriented method of measurement information processing on microclimate parameters. Methodology. The authors used experimental studying methods of the multichannel automatic information-measuring system of the regulated microclimate parameters to measurement monitoring, as well as simulation methods of the control systems based on Fuzzy-logic for the corresponding results obtaining. Results. The authors have designed and constructed an experimental model of the automated greenhouse, which meets the geometric, dynamic and kinematic similarity criteria to real industrial greenhouse complexes. The hardware and software of the monitoring and control system of the greenhouses microclimate has been synthesized using modern sensor and software technologies. The qualitative and quantitative parameters of fuzzy control implemented subsystems of heating, humidification, ventilation and artificial lighting of the growing zone, drip irrigation, carbon dioxide plant nutrition and mineral fertilizers dosing have been estimated. Originality. The main scientific results of the article are analysis and logical synthesis of existing results in the declared subject area, substantiation of the physical and chemical parameters list, qualitative and quantitative results analysis of the computerized system development. The prospective studies directions on the industrial greenhouses modernization using the development and implementation of the monitoring and climate control systems have been substantiated. Practical value. The main applied results are development of the structural and algorithmic system organization and software implementation of the operation modes. The analysis of the research results of proposed system confirmed the possibility of its use in real greenhouse conditions. References 11 , tables 7, figures 17 .

Key words: fuzzy control, greenhouse, microclimate, computerized system.

\section{REFERENCES}

1. Both, A. J., Benjamin, L., Franklin, J., Holroyd, G., Incoll, L. D., Lefsrud, M. G., Pitkin, G. (2015), "Guidelines for measuring and reporting environmental parameters for experiments in greenhouses", Plant Methods, no. 11, pp. 1-18.

2. Food and Agriculture Organization of the United Nations (2017), Good Agricultural Practices for greenhouse vegetable production in the South East European countries, FAO, Rome, Italy.

3. Sriraman, A., Mayorga, R. V. (2007), "Climate Control inside a Greenhouse: An Intelligence System Approach Using Fuzzy Logic Programming", Journal of Environmental Informatics, no. 10 (2), pp. 14-20.

4. Faouzi, D., Bibi-Triki, N., Mohamed, B., Abune, A. (2017), "Optimization, Modeling and Simulation of Microclimate and Energy Management of the Greenhouse by Modeling the Associated Heating and Cooling Systems and Implemented by a Fuzzy Logic Controller using Artificial Intelligence", Informatica, no. 41, pp. 317-332.

5. Budi, L. S., Wardhani, R. M. (2017), "The Application of Fuzzy Logic Control Systems on Harvesting Standard Operating Procedures Models of Sesame Crops in Indonesia", International Journal on Advanced Science, Engineering and Information Technology, no. 7 (3), pp. 1089-1097.
6. Izzuddin, T. A., Johari, M. A., Rashid, M. Z. A., Jali, M. H. (2018), "Smart irrigation using fuzzy logic method", ARPN Journal of Engineering and Applied Sciences, no. 13 (2), pp. 517-522.

7. Chandraprabha, Mrs., Uma, K. (2017), "Controlling of Green House Parameters through GSM and LabVIEW System", International Journal for Scientific Research \& Development, no. 5 (07), pp. 358-362.

8. Algarin, C. R., Cabarcas, J. S., Llanos, A. P. (2017), "Low-Cost Fuzzy Logic Control for Greenhouse Environments with Web Monitoring", Electronics, no. 6 (71), pp. 1-12.

9. Besekerskiy, V. A., Popov, E. P. (2003), Teoriya sistem avtomaticheskogo upravleniya: 4-e izd., pererab. $i$ dop. [The theory of automatic control systems: 4th ed., rev. and add.], Professiya, Saint Petersburg, Russia.

10. Laktionov, I. S., Vovna, O. V., Zori, A. A. (2017), "Planning of remote experimental research on effects of greenhouse microclimate parameters on vegetable crop-producing", International Journal On Smart Sensing and Intelligent Systems, no. 10 (4), pp. 845-862.

11. Laktionov, I., Vovna, O., Bashkov, Ye., Zori, A., Lebediev, V. (2019), "Improved Computer-Oriented Method for Processing of Measurement Information on Greenhouse Microclimate", Int. J. BIOautomation, no. 23 (1), pp. 71-86. 